\title{
Relationship Between Patriarchy And Customary Social Practices Affecting Women's Life In Pakistan
}

\author{
Naima Tabassum \\ Area Study Centre for Far East and South East Asia \\ University of Sindh \\ Huma Tabassum \\ Government Girls Degree College \\ Hyderabad \\ Tabassum Afzal \\ Government College of Education \\ Karachi
}

\begin{abstract}
Explaining the nature and prevalence of patriarchal culture and eight anti women socio-cultural practices (i.e. Dowry, Watta Satta, Walwar, Honour Killing, Wanni, Swara, Marriage with the holy book of Quran, and Child marriage), this paper explores a relationship between people's perceptions about patriarchy and anti women socio-cultural practices as sources of crime and violence against Pakistani women. The paper is based on primary data collected through survey conducted with a close ended questionnaire developed by the researcher. The collected data was statistically analyzed to test hypotheses. It argues that socio-cultural practices and the patriarchy are perceived as factors leading to crime and violence against Pakistani women. It is found that the respondents scoring higher on the scale for assessing perceptions regarding "patriarchy as a factor leading to crime against women" also score higher on the scale for assessing the "socio-cultural practices as factor leading to crime against women" in Pakistan. Therefore, it is inferred that there is a positive correlation between respondents' perceptions regarding patriarchy and socio-cultural practices as factors leading to crime against women in the country. It means patriarchy is the basic system that fosters crime and violence against women through the tools of anti women socio-cultural practices in Pakistan.
\end{abstract}

Keywords: Culture, Patriarchy, Social Practices, Women.

$$
\begin{aligned}
& \text { تلخيص }
\end{aligned}
$$

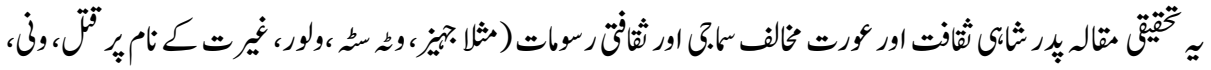

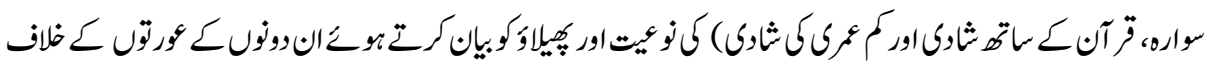

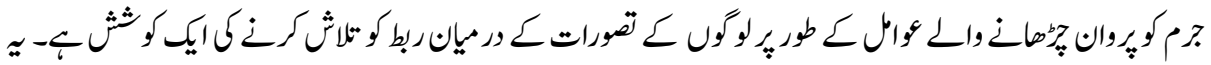




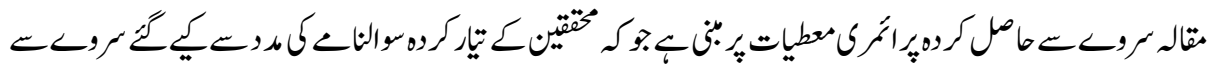

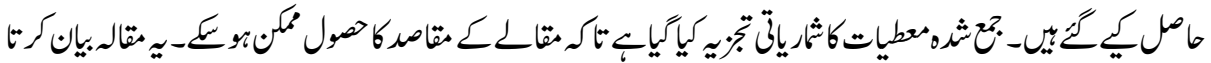

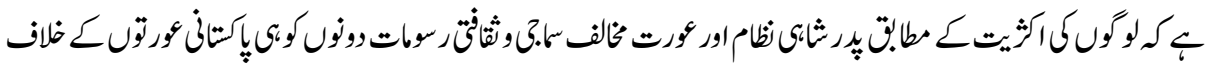

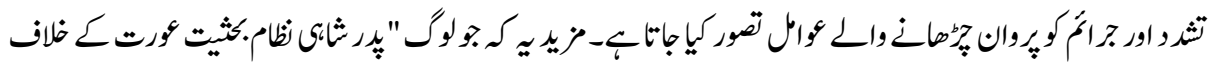

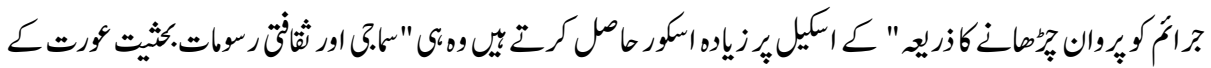

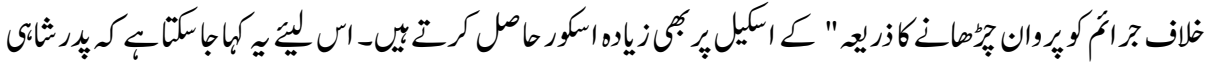

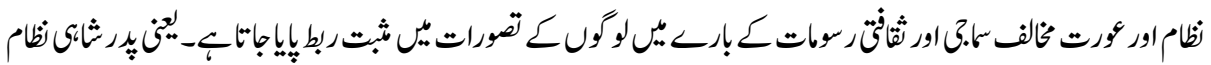

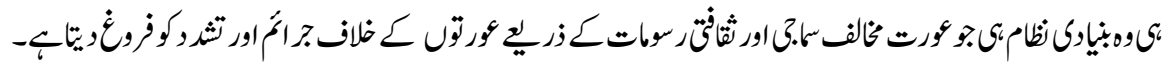

$$
\begin{aligned}
& \text { كليرى الفاظ:ثقافت بيدرثانى، ساكر بوات، خواتين }
\end{aligned}
$$

\section{Introduction}

Pakistan is a patriarchal society. Its culture embodies typical features of "classic patriarchy" (Kandiyoti, 1988). Like any patriarchal culture, Pakistani society is characterized with men's domination over women in all major avenues of power and authority giving them a privileged and center position in society. This social order results in women's subordination and oppression reducing them to underprivileged and vulnerable conditions of life. This gendered social order and patriarchal culture is evident in all aspects of social life.

Pakistani women are facing discrimination in social, cultural, economic and political domains of Pakistani society. Majority of them living with low educational, health and economic status segregated in the private spare of home unable to develop their social capital properly. They do not hold sufficient decision making power and resources to improve their life conditions. Their less powerful status make them vulnerable to crime and violence that is also condoned by culture and not sufficiently dealt by the men dominated social, legal and policy frameworks from home to state.

Culture plays an important role in determining different social, economic and political positions of individuals and groups within a society. Gender stereotypes are not natural. They are cultural products setting different codes of behaviour and conduct for men and women about daily practices and life patterns. The dominant groups in a society or culture have the political power to promote the practices and traditions that serve their interests better. At the same time they also possess the power to control the subordinate groups and prevent them from raising any voice against the practices promoted by the former but harmful for the latter. 
In patriarchal culture men are the dominant group possessing all the avenues of power and authority in groups and institutions from family to the state. They are the key players who on broader scale exercise their power on the subordinate groups to legitimize that social, cultural and traditional practices will be followed and praised any further and which of them will be curbed to the extent of their disappearance.

Pakistani society has a patriarchal culture. Where men possess this power to control women and legitimize all the social practices benefit them, even if they are harmful for any other subordinate group like women, children, elderly, weaker or disabled. They possess such powers from family to the state level, as women include the weaker and marginally represented ones at all levels of society. Women are socialized to be submissive to their male patriarchs within family as daughters and sisters. This weaker and submissive position led to less preference to their educational and economic empowerment.

Girls' education is considered secondary as compared to their male siblings within family. The lower level of educational attainment combined with the prevailing notions that "women do not work" or "women should remain in the four walls of home" lead to poor prospects of paid work opportunities. It makes them socially and economically reliant on men. Their entrance is public sphere where most of the social, economic and political opportunities lay is restricted and controlled. In this way, as soon as the power struggle comes out of home, women got vanished from the scene and only it remains as a struggle for resources and power among men and group of men.

This masculine struggle and women's disappearance is visible in Pakistani society. The representation of women's point of view in the communal and national level legitimization process of social practices becomes marginal to the extent of mere absence. Consequently, the social order, with all the social and cultural practices beneficial for men even if they are harmful for women, is again legitimized by the dominant groups of men at family, community and national level. So the vicious circle of exercising anti-women social practices, legitimizing them through formal and informal norms and laws and reproducing them goes on and on. This vicious cycle shows that there is a mutually reproducing link between patriarchal culture (men's domination over women) and persistence of anti-women social, cultural and traditional practices in any society. There is still not sufficient research with empirical data available which comprehensively studying this important link between the two phenomenon of patriarchy and anti-women social practices in the context of Pakistan. Accordingly, this paper is an effort to fill this research gap.

This paper is part of the broader research on causes of crime and violence against women 
in Pakistan. It particularly focused on two broader phenomena of patriarchy and anti women socio-cultural practices prevailing in Pakistan. These two factors also play important role in fostering crime and violence against Pakistani women. The paper focuses on people's perception regarding these two factors effecting crime and violence against women in Pakistani society. It also establishes a relationship between the perceptions on these two phenomena showing that patriarchal culture results in harmful social and cultural practices that reduce women's status in society to consolidate and reproduce the culture of patriarchy in turn.

\section{Review of Literature}

Patriarchy is the basic feature of Pakistani society (Shaheed 1991, 135-158). In the patriarchal societies men holds the dominant position as compared to women in all walks of social life (Johnson 1997, 5; Millett 1970, 25). Men rule and monopolized the public sphere while women's entrance in this public sphere is restricted. Women are being assigned with the private sphere (i.e. home) to spend most part of their lives. In the private sphere of home they are ruled by the family men patriarchs. This all social order of exclusion from public sphere and subordination to household men head within the private sphere of home led to lower socio-economic status and vulnerability to violence and crime against them.

Consequently, women lack in education, their access to health is poor, their labour force participation is low, and their say and representation in political and legislative decision making is marginal. Pakistani women have less access to educational facilities. Women's literacy level was lower as only $32 \%$ in comparison to that of men as $54 \%$ in the year 1998 (Population Census Organization 1998a). The literacy rate among rural women was much lower as only $20 \%$. This situation did not progress much till today. According to Pakistan Social and Living Standard Measurement Survey 2013-14, Pakistani women's literacy rate is as low as $47 \%$ at national level; including $66 \%$ for urban women and only $36 \%$ for rural women (Government of Pakistan 2015, 50).

Pakistani Women's achievement in formal education sector is also not satisfactory. The formal educational facilities are also less in number for women than for men as only $33 \%$ of the primary schools are for girls (National Education Management Information System 2011). The enrollment of girl child in formal schools was also no more than $30 \%$ in last census (PCO 1998a). Pakistani girls have difficulty in access to educational facility and whoever succeeds in reaching there is always at a risk of getting dropped out of the school without completing her education due to several socio-cultural barriers. It is evident from the reported statistics that only $28 \%$ of the total enrolled girl students in one class in 2004-05 could pass 10 ${ }^{\text {th }}$ class successfully in 2013-14 (National Education Management Information System 2015). The socio-cultural barriers to women's 
education are many such as the girl has grown up and not need to go out of home, investing in boy's education will give returns but in girls education is a waste, puradah (veil), early marriage, etc. are to name a few.

Pakistani women's poor education is also linked with their poor health status. Tabassum (2016, 72-73) has highlighted a link between women's educational achievement and different health indicators like use of contraceptive, chances of being attended by a skilled health provider and accessing a health facility for delivering baby. She further highlights that there are several socio-cultural factors that are critically affecting women's health conditions in Pakistan, especially in rural areas of the country. The traditional cures are given first preferences within family for curing a woman. If need to consult a professional for cure even then the first choice is mostly to go to a quack (traditional Hakim) or a religious or spiritual healer (e.g. Peer) (Tabassum 2016, 73).

Women are also at a disadvantageous position in the formal work sector. The last census also shows a $2.23 \%$ labour force participation rate for women against $59.24 \%$ for men (Population Census Organization 1998b). This rate did not progress much till today. Labour Force Survey 2013-14 shows a crude labour force participation rate in Pakistan as $32.2 \%$; including 48\% for men and 15.8\% for women (Government of Pakistan 2014, 76). Besides the lower labour force participation rate, women in labour market of Pakistan are also facing the problems of gender discrimination, sticky floors and glass ceilings. Channar, Abbassi, and Ujan (2011) aptly identify that Pakistani women are facing more gender discrimination in the private sector and it badly effects their satisfaction and motivation at workplace. Women are mostly segregated in the lowest tiers of occupational hierarchy and face difficulty and unseen barriers in climbing up in this hierarchy. Ahmed and Hyder (2008) found in their research that Pakistani women are facing gender wage gap and it is more increasing in the private sector and at the lower levels of occupational hierarchies where most of Pakistani women workers are segregated.

Tabassum $(2016,76)$ has highlighted the fact that this poor condition of women in labour market is also determined by certain socio-cultural perceptions and practices. She identify that the traditional stereotypical notions about men as bread winner and women as home maker are at the basis of differential segregation of men and women in paid and unpaid work. It has resulted in devaluation of women's work. This culturally determined differential position of men and women in terms of value of their work also led to their different economic and political standing in the patriarchal hierarchy.

The exclusion of Pakistani women from power and authority positions is also the result of this broader social and cultural patriarchal setup. Tabassum $(2016,151)$ describes that women and men in Pakistani society are socialized since their birth to occupy different 
social and power positions in the patriarchal hierarchy. This socialization moulds women to be submissive and men to be controlling. Therefore, women remain submissive in family as daughters, sisters and wives obeying their fathers, brothers and husbands in all sorts of decisions. At community level, women are excluded from the public sphere and their representation in the public sphere can only be accepted through their men. In this manner, their identity gets subsumed within the identity of their men outside the premises of their home. Consequently, they found no representation at the communal level.

Similarly, Pakistani women's representation in formal political forum also remained poor. Since 1993, women comprise only $45 \%$ to $46 \%$ of the total voters in Pakistan (Tabassum 2016, 170). Tabassum (2016, 172-175) has highlighted the socio-cultural barriers hampering women's right to cast vote. She identifies several barriers such as due to lack of education women face more problems related in their ID cards and voter lists, veiling and restricted mobility also hamper their chance to reach voting place, and the religious leaders, regional elites and the political parties are also some times making alliances to stop women from voting. Shaheed $(2002,131)$ in her research found that $74 \%$ of the women in Pakistan do not vote due to the technical reasons related to ID card and voter lists. Naz, Ibrahim, and Ahmed $(2012,167)$ in their research on barriers to women's political participation in Pakhtoon society identify that $13 \%$ women considering the strict Prudah (veil) as a barrier in casting vote. Aurat Foundation (2001) has provided a large number of documents of agreements among local men and political parties in NWFP and FATA restricting women from casting votes in elections.

Further, Pakistani women's representation in the parliament remained marginal till the year 2002; for example their representation in national assembly was no more than 3\% by the year 2000 (Syed and Tabassum 2014; Syed, Tabassum, and Afzal 2013; Syed, Tabassum and Afzal 2015). Their representation was only one woman member out of 483 members in four provincial assemblies in 1997 (Asian Development Bank 2000). The number of women in parliament and provincial assemblies has increased after 2002 but it is still very low that is no more than $17 \%$ to $21 \%$ at different forums in different time periods.

The above described male dominated patriarchal culture of society, prevailing from family to the state level, fosters the cultural practices that are favorable for men even when they are discriminatory and harmful for women. Pakistani women have a long history of facing social, cultural, legal, political and economic discrimination and violence. The available reports on statistics for incidences of crime and violation against women are identifying a large variety of offences occurring against women in the country (Azhar 2012; Perveen 2013). These include domestic violence, exchange and forced marriages, kidnapping, murders, rapes, and honour killings, etc. 
The available statistics show an increasing trend in the number of incidences of these types of crime against women in Pakistan. The number of reported cases for abduction and kidnapping is reported as 1607 in the year 2012. The cases of murders reported were 1745 in the same year. The number of incidences of domestic violence reported across the country were 989 in the year 2012. The reported cases of rape or gang rape were counted as 822 in the year 2012. The reported incidences of Acid attacks were 83 in the same year. 71 cases of burning of women also include these reports. Other than these categories of crime a large number of crimes (i.e. 1134 case) is reported in the category of miscellaneous crimes. This large category of crimes includes a large variety of crimes occurring in the name of cultural or social practices (Azhar 2012; Perveen 2013).

The crimes and violence against women also include a large variety of socio-cultural practices that are harmful for women (Jilani and Ahmed 2004). These anti women cultural practices reduced women's status to a commodity for men to be used and utilized for their social and political gains. There is a variety of cultural practices that foster exchange and forced marriages in Pakistani society. Watta Satta (exchange marriage) is a common practice of giving a woman in marriage from one family in promise of/ or exchange of another woman from groom's family in marriage with a man in brides' family (Jilani and Ahmad 2004, 194; Ali 2001:6). This practice reduces the choice of mate selection for women and limit and conditioned their mate possibilities with the convenience and choice of their family men.

Wani and Swara are also two cultural practices to be practiced in Khyber Pakhtoonkhwa and Balochistan provinces in which women are being exchanged for settling the tribal disputes of murder and financial loss among men (Abbas and Riaz 2013; Noor 2004). These women are given as a blood money to victim's family in murder cases (Shah 1998; Zuhur 2005). Walwar is a practice of selling girls in marriage for money (Jilani and Ahmed 2004, 194). Child marriage is also common in the rural areas of the country. Marriage with Quran is a cultural practice of getting women married with Quran (the holy book) in order to make her withdrawal from the right to get married with a man, with the aim of protecting the family property from division in the case of her marriage (Jilani and Ahmed 2004, 195; Iqbal 2007; Noor 2004; Yefet 2009, 365).

Honour Killing is simply explained as the killing of a person in the name of family honour that disproportionately victimized women as compared to men (Ali 2001; Jilani and Ahmed 2004). The available statistics show a sufficient number of honour killings occurring in Pakistan every year. The number of honour killing cases reported was 475 in the year 2008, 605 in the year 2009, 557 in the year 2010, 705 in the year 2011, and 432 in the year 2012 (Azhar 2012; Perveen 2013).

Dowry is a cultural practice of giving gifts and property to bride at the time of her 
marriage as facilitation to start a new home (Gulzar et al. 2012, 784). The nature of the gifts and assets has changed with the passage of time. From its original concept of gifts, now dowry has come to include, cloths, crockery, household appliances, furniture, jewelry, gold, silver, cash money, motor cycle, car, and even property like home etc. Therefore, now it has become a burden on parents of the bride and frequently results in violence against women in the new house where she is married and still this practice is widely prevalent and acceptable in the country (Gulzar et al. 2012, 784). In this way, the dowry has also become linked with the domestic violence and abusive treatment of the women in her new home (Ali, Árnadóttir, \& Kulane 2013, 84-85).

There is a variety of causes that foster and condone these social practices leading to crimes against women in Pakistani society for long. There are studies that have identified several social, cultural, legal and political causes for persisting crime against women in Pakistan (Tabassum, Tabassum, \& Afzal, 2013). The broader culture of patriarchy and the cultural practices are considered two main causes among others to affect the long existence of crime against women in the country. The crime and violence against women appear to have occurring in a large number due to the lower socio-economic and political status of women assigned to them by the patriarchal culture and anti women sociocultural practices. Therefore, this paper particularly focuses on these two phenomena. It explores the relationship between perceptions on patriarchy as a source of crime and socio-cultural practices as factors effecting crime against women in the country.

\section{Objectives of the Study}

1. To explore people's perceptions regarding potential of socio cultural practices as a factor leading to crime against women in Pakistan.

2. To explore people's perception regarding potential of patriarchy as a factor leading to crime against women in Pakistan

3. To explore a relationship between people's perceptions regarding patriarchy and anti women socio-cultural practices as factors effecting crime and violence against women in the country.

\section{Research Hypotheses}

$\mathrm{H}_{1}$. The majority of respondents consider socio cultural practices as a factor effecting crime against Pakistani women.

$\mathrm{H}_{2}$. The majority of respondents consider patriarchy as a factor effecting crime against Pakistani women.

$\mathrm{H}_{3}$. There is a positive correlation between people's perception on patriarchy as a factor effecting crime against women and socio-cultural practices as factor effecting crime against Pakistani women. 


\section{Research Methodology}

The paper is part of broader research on causes of crime and violence against women in Pakistan. It focuses on two particular phenomena of patriarchy and anti women sociocultural practices in Pakistan. The research is exploratory in nature. It aims to explore the relationship between people's perception on two phenomena of patriarchy and social practices as sources of crime and violence against Pakistani women.

The research study follows the quantitative approach to data collection and analysis. The method for data collection is survey method. Educated people of Sindh are the respondents of the survey. Total 216 people served as respondents for this research. A close ended questionnaire with 27 items developed by the researcher with five point Likert scale is used as the tool or instrument for data collection. The questionnaire was pre-tested and the reliability of the tool appeared sufficiently good as alpha (0.859).

The data was first entered into computer and analyzed with the help of SPSS 11.5. For the analysis of data to test the hypotheses, the researcher calculated frequencies and correlation coefficients to test the hypothesis claiming the relationship between two phenomena of educated people's perceptions on patriarchy and socio-cultural practices as sources of crime.

\section{Data Analysis and Results}

This paper focuses on two phenomena of patriarchy and socio-cultural practices. According to the aims and objectives of this paper, this section of the paper is presenting data analysis and finding in three major sub sections. First, it explores people's perceptions regarding different socio-cultural practices as sources of crime and violence against women with the help of data analysis. Second, it explains the patterns of people's perceptions regarding patriarchy as a source of crime against women. Finally, the paper investigates a potential relationship between people's perceptions regarding patriarchy and anti women socio-cultural practices as sources of crime and violence against women in the country.

People's perceptions on the socio-cultural practices as sources of crime are presented here. Majority of the respondents (i.e. more than 80\%) agree that socio-cultural practices are affecting crime against women in the country. Only 9\% respondents showed their disagreement with this phenomenon. Another $9.3 \%$ of the respondents were found unaware in this regard.

The data analysis also shows statistics on eight socio-cultural practices for people's perception regarding each of these perspectives' as source of crime, separately. It is 
shown that more than $75 \%$ of the respondents consider cultural practice of dowry as a factor giving rise to crime against women in country. Only $12 \%$ respondents are not considering dowry as a source of crime against women. Another $12 \%$ respondents neither agreed nor disagreed with this phenomenon due to their lack of knowledge in this regard.

The socio-cultural practice of Watta Satta (exchange marriage) is also agreed by more than $91 \%$ of the respondents as factor effecting crime against women in Pakistan. Only $5.6 \%$ respondents do not consider this practice as harmful for Pakistani women's social status. Still $2.8 \%$ respondents did neither agree nor disagree in this regard.

Table: 1

People's perception on potential of socio-cultural practices for fostering crime against women in Pakistan

\begin{tabular}{|l|c|c|c|c|c|}
\hline Item & $\begin{array}{c}\text { Strongly } \\
\text { Disagree }\end{array}$ & Disagree & $\begin{array}{c}\text { Do not } \\
\text { Know }\end{array}$ & Agree & $\begin{array}{c}\text { Strongly } \\
\text { Agree }\end{array}$ \\
\hline $\begin{array}{l}\text { Socio-cultural } \\
\text { practices }\end{array}$ & $\begin{array}{c}2 \\
(0.9 \%)\end{array}$ & $\begin{array}{c}18 \\
(8.3 \%)\end{array}$ & $\begin{array}{c}20 \\
(9.3 \%)\end{array}$ & $\begin{array}{c}120 \\
(55.6 \%)\end{array}$ & $\begin{array}{c}56 \\
(25.9 \%)\end{array}$ \\
\hline Dowry & 0.0 & 26 & 26 & 94 & 70 \\
& $(0.0 \%)$ & $(12.0 \%)$ & $(12.0 \%)$ & $(43.5 \%)$ & $(32.4 \%)$ \\
\hline Watta Satta & 4 & 8 & 6 & 78 & 120 \\
& $(1.9 \%)$ & $(3.7 \%)$ & $(2.8 \%)$ & $(36.1 \%)$ & $(55.6 \%)$ \\
\hline Walwar & 2 & 10 & 22 & 72 & 110 \\
& $(0.9 \%)$ & $(4.6 \%)$ & $(10.2 \%)$ & $(33.3 \%)$ & $(50.9 \%)$ \\
\hline Honour Killing & 2 & 10 & 24 & 42 & 138 \\
& $(0.9 \%)$ & $(4.6 \%)$ & $(11.1 \%)$ & $(19.4 \%)$ & $(63.9 \%)$ \\
\hline Marriage with & 0.0 & 8 & 14 & 52 & 142 \\
Quran & $(0.0 \%)$ & $(3.7 \%)$ & $(6.5 \%)$ & $(24.1 \%)$ & $(65.7 \%)$ \\
\hline Wanni & 0.0 & 2 & 14 & 62 & 138 \\
& $(0.0 \%)$ & $(0.9 \%)$ & $(6.5 \%)$ & $(28.7 \%)$ & $(63.9 \%)$ \\
\hline Swara & 2 & 2 & 18 & 66 & 128 \\
& $(0.9 \%)$ & $(0.9 \%)$ & $(8.3 \%)$ & $(30.6 \%)$ & $(59.3 \%)$ \\
\hline Child marriage & 2 & 14 & 12 & 100 & 88 \\
& $(0.9 \%)$ & $(6.5 \%)$ & $(5.6 \%)$ & $(46.3 \%)$ & $(40.7 \%)$ \\
\hline
\end{tabular}

The social practice of Walwar (selling girls in marriage for money) is considered as social practice resulting in crime against women by more than $84 \%$ of the respondents. Still the data analysis shows $5.5 \%$ respondents remaining disagree with this association of the social practice of Walwar with crime and violence against women.

Honour Killings is being perceived as potential cultural praxis leading to crime against women by $83 \%$ of the research participants. Only $5.5 \%$ of the respondents do not 
consider the practice of honour killing as causing crime and violence against women in Pakistan. Besides that $11 \%$ respondents neither agreed nor disagreed to this phenomenon of Honour killing as a source of causing crime against women.

Marriage with the holy book of Quran is confirmed as a crime against women by $90 \%$ of the respondents. Only a marginal number of research participants either showed their lack of knowledge or disagreed with this phenomenon of that this kind of marriage results in violation of women's rights.

Wani and Swara (the practices for exchanging women to settle the disputes among men) are considered leading to crime against women in the country by more than $92 \%$ and $90 \%$ of research participants, respectively. Less than $1 \%$ of the respondents disagree with the idea that this social practice has the potential to cause crime and violence against women in the country. Similarly, only less than $2 \%$ of the respondents showed their disagreement with the potential of the social practice of swara for causing violence against women in Pakistan.

Child marriage is a common practice leading to crime against women in rural areas of country is confirmed by $87 \%$ of the respondents as having potential for causing crime against Pakistani women. Only $7.4 \%$ respondents disagree with the concept that child marriage is harmful for women.

At the overall level, the data analysis shows that majority of the respondents consider all these eight socio-cultural practices of dowry, watta satta, walwar, honour killing, marriage with Quran, wanni, swara, and child marriage as source of fostering crime and violence against Pakistani women. In this way, on the basis of the results of data analysis presented above, safely accept Hypothesis $1\left(\mathrm{H}_{1}\right)$ stating that the majority of respondents consider socio-cultural practices as a factor effecting crime against Pakistani women.

Table: 2

People's perception on the potential of two main features of patriarchy for fostering crime against women

\begin{tabular}{|l|c|c|c|c|c|}
\hline Item & $\begin{array}{c}\text { Strongly } \\
\text { Disagree }\end{array}$ & Disagree & $\begin{array}{c}\text { Do not } \\
\text { Know }\end{array}$ & Agree & $\begin{array}{c}\text { Strongly } \\
\text { Agree }\end{array}$ \\
\hline $\begin{array}{l}\text { Male domination over } \\
\text { women }\end{array}$ & $\begin{array}{c}6 \\
(2.8 \%)\end{array}$ & $\begin{array}{c}24 \\
(11.1 \%)\end{array}$ & $\begin{array}{c}14 \\
(6.5 \%)\end{array}$ & $\begin{array}{c}102 \\
(47.2 \%)\end{array}$ & $\begin{array}{c}70 \\
(32.4 \%)\end{array}$ \\
\hline $\begin{array}{l}\text { Women's segregation in the } \\
\text { private sphere of home }\end{array}$ & $\begin{array}{c}2 \\
(0.9 \%)\end{array}$ & $\begin{array}{c}28 \\
(13.0 \%)\end{array}$ & $\begin{array}{c}34 \\
(15.7 \%)\end{array}$ & $\begin{array}{c}100 \\
(46.3 \%)\end{array}$ & $\begin{array}{c}52 \\
(24.1 \%)\end{array}$ \\
\hline
\end{tabular}

The data analysis is also done to analyze the patterns of popular perceptions on patriarchy as a cultural feature leading to crime against women. Here two major patriarchal 
characteristics that make a society classic patriarchy are focused. The two patriarchal features namely are male domination over women and women's segregation in the private sphere of home.

The data analysis shows that majority (i.e. almost $80 \%$ ) of the respondents consider patriarchal feature of male domination over women as a factor that fosters victimization of Pakistani women. At the same time, only $13.9 \%$ of research participants do not consider this male domination over women in Pakistan as a source of women's victimization in the country. Only $6.5 \%$ respondents were found unaware in this regard.

The data analysis further shows that more than $70 \%$ of the respondents consider the patriarchal segregation of women in the private sphere of home as a potential source of their poor and vulnerable conditions to violence and crime. There are $13.9 \%$ of the research participants disagree with this potential of fostering crime against women embodied in their social segregation within home. Only $15.7 \%$ respondents did not chose to either agree or disagree with this negative potential of women's segregation in the private sphere of home. On the basis of above presented data analysis and results, it is safe to accept the Hypothesis $2\left(\mathrm{H}_{2}\right)$ stating that the majority of respondents consider patriarchy as factor effecting crime against Pakistani women.

Finally, the paper investigates a potential relationship between people's perceptions regarding patriarchy (PA) and anti women socio-cultural practices (SC) as sources of crime and violence against women in the country. The analysis of data is presented the following results. It shows the Pearson correlation calculated for ascertaining the relationship between the scores the respondents have achieved on two scales exploring these two phenomenon.

Table: 3

Correlations

\begin{tabular}{|l|l|r|r|}
\hline & & PA & \multicolumn{1}{|c|}{ SC } \\
\hline PA & Pearson Correlation & 1 & $.272(* *)$ \\
\hline & Sig. (2-tailed) &. & .000 \\
\hline & N & 216 & 216 \\
\hline SC & Pearson Correlation & $.272\left(^{* *}\right)$ & 1 \\
\hline & Sig. (2-tailed) & .000 & 216 \\
\hline & N & 216 &. \\
\hline
\end{tabular}

** Correlation is significant at the 0.01 level (2-tailed).

In order to ascertain the correlation between the two variables, Pearson Product-moment Correlation was calculated. The analysis of data shows that there is a positive correlation between people's score on the scale for perceptions regarding patriarchy as a factor 
effecting crime against women and the scale on perceptions on scale for socio-cultural practices as factor leading to crime against Pakistani women. In the above table, the data analysis shows that Pearson Product-moment Correlation $(r)=0.272$, and the confidence level is $(\mathrm{Sig}=0.000)$. It means $\mathrm{p}<0.01$. It shows that there is a statistically significant positive correlation between the scores on two scales for people's perception regarding patriarchy as a factor effecting crime against women and the perception regarding sociocultural practices as a factor leading to crime against Pakistani women.

Table: 4

Model Summary

\begin{tabular}{|l|c|c|c|c|}
\hline Model & R & R Square & $\begin{array}{c}\text { Adjusted R } \\
\text { Square }\end{array}$ & $\begin{array}{c}\text { Std. Error of the } \\
\text { Estimate }\end{array}$ \\
\hline 1 & $.272^{(\mathrm{a})}$ & .074 & .069 & 5.44970 \\
\hline
\end{tabular}

a Predictors: (Constant), PA

The regression analysis is done to ascertain that this result does not occur due to some sampling error or by chance. The independent variable was the score on scale for perception on patriarchy as a factor affecting crime against Pakistani women. The dependent variable was the score on scale for perceptions on socio-cultural practices as factors leading to crime against women. The results of data analysis show that $\mathrm{r}=0.272$ and $\mathrm{r}^{2}=0.074$. It further shows the Adjusted $\mathrm{r}^{2}=0.069$.

Table: 5

$\operatorname{ANOVA}^{(\mathbf{b})}$

\begin{tabular}{|l|l|c|c|c|c|c|}
\hline Model & & $\begin{array}{c}\text { Sum of } \\
\text { Squares }\end{array}$ & Df & $\begin{array}{c}\text { Mean } \\
\text { Square }\end{array}$ & F & Sig. \\
\hline 1 & Regression & 506.367 & 1 & 506.367 & 17.050 & $.000^{\text {(a) }}$ \\
\hline & Residual & 6355.633 & 214 & 29.699 & & \\
\hline & Total & 6862.000 & 215 & & & \\
\hline
\end{tabular}

a Predictors: (Constant), PA

b Dependent Variable: SC

The Analysis of Variance shows that $\mathrm{F}$ - value $=17.050$ and the confidence value $=.000$ (i.e. very significant). Therefore, the above correlation results do not appear due to any sampling error. It shows that the regression line is different from zero. 
Table: 6

Coefficients $^{(\mathbf{a})}$

\begin{tabular}{|l|l|c|c|c|c|c|}
\hline Model & & \multicolumn{2}{|c|}{$\begin{array}{c}\text { Unstandardized } \\
\text { Coefficients }\end{array}$} & $\begin{array}{c}\text { Standardized } \\
\text { Coefficients }\end{array}$ & $\mathrm{t}$ & Sig. \\
\hline & & $\mathrm{B}$ & $\begin{array}{c}\text { Std. } \\
\text { Error }\end{array}$ & Beta & & \\
\hline 1 & (Constant) & 31.861 & 1.493 & & 21.340 & .000 \\
\hline & PA & .788 & .191 & .272 & 4.129 & .000 \\
\hline
\end{tabular}

${ }^{a}$ Dependent Variable: SC

The results of data analysis further shows slope of regression line $(B)=0.788$ and a $t$-value $=4.129$. The confidence value $(\mathrm{Sig}=.000)$. The $\mathrm{B}=0.788$ means that every rise of one unit for independent variable (i.e. score on scale for perceptions regarding patriarchy as a source of crime against women in Pakistan) predicts a rise on the dependent variable (i.e. score on scale for perceptions regarding socio-cultural practices as source of crime) of 0.788 unit. The Constant of 31.861 is the predicted score on socio-cultural practice scale if a respondent scores zero on patriarchy scale.

The above data analysis show that this study found that there is a statistically significant positive correlation existing between the scores on two scales for people's perception regarding patriarchy as factor effecting crime against women and the perception regarding socio-cultural practices as the factor effecting crime against women in Pakistan. It was evident from the statistical values of $\mathrm{r}=0.272$ with a confidence level of $p<0.01$ in Table 3. On the basis of above presented test results, the Hypothesis $3\left(\mathrm{H}_{3}\right)$ stating that there is a positive correlation between people's perception on patriarchy as a factor effecting crime against women and socio-cultural practices as factor effecting crime against Pakistani women is safely accepted.

\section{Conclusions}

To determine the relationship between two variables in focus in this research, the statistical test was done to calculate the correlation. The results show $r=0.272$ with a confidence level of Sig=0.000. Further, the Analysis of Variance shows that the regression result is significantly different from zero $(F=17.050, \mathrm{p}<0.01)$. Hence our result did not occur by chance and consistent with our research hypothesis. It shows that the rise in the score on the scale for perceptions on patriarchy as a factor effecting crime against women raises the score of respondents on scale for perception regarding socio-cultural practices as factor leading to crime against women. It is inferred that there is a significant 
positive relationship between the two sets of perceptions of respondents.

On the above analysis of data, it is found that those people scoring higher on the scale for assessing perceptions regarding "patriarchy as a factor affecting crime against women" are also scoring higher on the scale for assessing the "socio-cultural practices as a factor leading to crime against women" in the country. Therefore, it is inferred that there is a positive correlation between people's perceptions regarding patriarchy as a factor affecting crime against women and the prevailing socio-cultural practices as factor leading to crime against women. It means patriarchy is the basic system that fosters crime and violence against women through the tools of anti women socio-cultural practices in Pakistan.

\section{References}

Abbas, M. Z. \& Riaz, S. (2013). Legal Protections Provided Under Pakistani Law against Anti-Women Practices: Implementation Gaps between Theory and Practice. The Dialogue, vol.8:2, pp.172-185.

Ahmed, A. M. \& Hyder, A. (2008). Sticky Floors and Occupational Segregation: Evidence from Pakistan. The Pakistan Development Review, vol.47:4, pp.837-849.

Ali, R. (2001). The Dark Side of Honour: Women Victims in Pakistan. Lahore: Shirkat Gah Women Resource Centre, pp.10.

Ali, T. S., Árnadóttir, G. \& Kulane, A. (2013). Dowry Practices and their Negative Consequences from a Female Perspective in Karachi, Pakistan: A Qualitative Study. Health, vol.5:7, pp.84-91.

Asian Development Bank (2000). Country Briefing Paper: Women in Pakistan, viewed 9 September 2013, http:/www.adb.org/sites/default/files/pub/2000/women_pakistan.pdf

Aurat Foundation. (2001). A Public Case on Gross Violation of Women's Electoral Rights in Swabi, Mardan and Dir, NWFP. Islamabad: Aurat Publication and Information Service Foundation.

Azhar, N. (2012). Violence against Women in Pakistan: A Qualitative Review of Statistics for 2011. Islamabad: Aurat Publication and Information Service Foundation. 
Channar, Z. A., Abbassi, Z. \& Ujan, I. A. (2011). Gender Discrimination in Work Force and its Impact on the Employees. Pakistan Journal of Commerce and Social Sciences, vol.5:1, pp.177-191.

Government of Pakistan. (2014). Compendium on Gender Statistics of Pakistan 2014. Islamabad: Federal Bureau of Statistics.

Government of Pakistan. (2015). Pakistan Social and Living Standards Measurement Survey (2013-14): National/Provincial Report. Islamabad: Statistics Division, Pakistan Bureau of Statistics.

Gulzar, S., Nauman, M., Yahya, F., Ali, S. \& Yaqoob, M. (2012). Dowry System in Pakistan. Asian Economic and Financial Review, vol.2:7, pp.784-794.

Iqbal, N. (2007) Legal Pluralism in Pakistan and its Implications on Women's Rights (101-117). In Bennett, J. (ed.) Scratching the Surface: Democracy, Traditions, Gender. Pakistan: Heinrich Böll Foundation.

Jilani, H. \& Ahmed, E. M. (2004). Violence Against Women: The Legal System and Institutional Responses in Pakistan. In S. Goonesekere (Ed.), Violence Law \& Women's Rights in South Asia (pp. 148-206). New Delhi: Sage Publication.

Johnson, A. (1997). The Gender Knot: Unraveling Our Patriarchal Legacy. Philadelphia: Temple University Press.

Kandiyoti, D. (1988) Bargaining with Patriarchy. Gender and Society, vol.2:3, pp.274-290.

Millett, K. (1970). Sexual politics. New York: Doubleday.

National Education Management Information System. (2011). Pakistan Education Statistics 2010-11. Islamabad: Academy of Educational Planning and Management.

National Education Management Information System. (2015). Pakistan Education Statistics 2013-14. Islamabad: Academy of Educational Planning and Management.

Naz, A., Ibrahim \& Ahmed, W. (2012). Socio-Cultural Impediments to Women Political Empowerment in Pakhtun Society. Academic Research International, vol.3:1, pp.163-173, retrieved on July 24, 2016 from: http://www.savap.org.pk/journals/ ARInt./Vol.3(1)/2012(3.1-21).pdf 
Noor, J. (2004). Daughters of Eve: Violence against Women in Pakistan. Unpublished Bacholor's thesis. Massachusetts Institute of Technology, Massachusetts.

Perveen, R. (2013). Beyond Denial: Violence against Women in Pakistan-A Qualitative Review of Reported Incidents (January-December 2012). Islamabad: Aurat Publication and Information Service Foundation.

Population Census Organization. (1998a). Demographic indicators- 1998 Census, retrieved August 29, 2013, from: http://www.census.gov.pk/ DemographicIndicator.htm

Population Census Organization. (1998b). Labour Force Participation Rates, retrieved August 29, 2013, from: http://www.census.gov.pk/LabourForce.htm

Shah, H. Q. (1998). Reflections on the Law of Qisas and Diyat. In F. Shaheed, S. A. Warraich, C. Balchin, \& A. Gazdar. (Eds.). Shaping women's lives: Laws, Practices \& Strategies in Pakistan (pp. 253-267). Lahore: Shirkat Gah.

Shaheed, F. (1991). The Cultural Articulation of Patriarchy. In F. Zafar (Ed.), Finding Our Way: Readings on Women in Pakistan (pp. 135-158). Lahore: ASR Publications.

Shaheed, F. (2002). Imagined Citizenship: Women, State and Politics in Pakistan. Lahore: Shirkat Gah Women's Resource Centre.

Syed, N. T. \& Tabassum, H. (2014). Women's Political Participation in Pakistan. Pakistan Journal of Gender Studies, vol.8, pp.131-143.

Syed, N. T., Tabassum, H. \& Afzal, T. (2015). Women's Representation in National Assembly of Pakistan. Grassroots: Biannual Research Journal of Pakistan Study Centre, vol.49:1.

Tabassum, N. (2016). Women in Pakistan: Status in Socio-Cultural and Politico-Legal Domains. Islamabad: Higher Education Commission of Pakistan.

Tabassum, N., Tabassum, H. \& Afzal, T. (2013). Social Practices Fostering Crime against Women and the Law in Pakistan. International Research Journal of Arts \& Humanities (IRJAH), vol.4:41, pp.305-327.

Yefet, K. C. (2009). What's the Constitution Got to Do with it? Regulating Marriage in Pakistan. Duke Journal of Gender Law \& Policy, vol.16, pp.347-377. 
Zuhur, S. (2005). Gender, sexuality and the Criminal Laws in the Middle East and North Africa: A Comparative Study. Istanbul, Turkey: Women for Women's Human Rights-New Ways.

Dr. Naima Tabassum is an Assistant Professor in the Area Study Centre for Far East and South East Asia University of Sindh, Jamshoro.

Ms. Huma Tabassum is an Assistant Professor in the Government Girls Degree College Latifabad No. 8, Hyderabad, Sindh.

Ms. Tabassum Afzal is Lecturer in the Government College of Education, Karachi. 